\title{
Analysis on Developing State and Optimizations of Leading Civil- military combination Industry of Hunan Province
}

\author{
Minhui Tong ${ }^{1,}$, Xiaofen $\mathrm{Li}^{2, \mathrm{~b}}$ \\ ${ }^{1}$ Management\& Economics School, Jingdezhen Ceramic Institute, Jingdezhen 333403, China; \\ ${ }^{2}$ Management Department, Nanning University, Nanning 530200, China; \\ atongminhuicom@163.com, b546267563@qq.com
}

Keywords: Hunan province, civil-military combination industry, developing state, optimizations.

\begin{abstract}
Regional developing phase, demand structure, factor endowment, industry policy, auxiliary industry development and income elasticity are used to estimate leading civil-military combination industry of Hunan province based on its developing state, then putting forward 3 policy suggestions including focusing 2-3 industries, deepening industrial development and synchronizing national policy, aims to promote development of civil-military combination industry of Hunan province.
\end{abstract}

\section{Introduction}

As a military industry province, Hunan province has been made big progress in development of civil-military combination industry recently, which realizes 109.6 billion main business income at year 2016 and gets 8.2\% year-on-year growth, having 3 national civil-military combination demonstration base including Zhuzhou aviation industry park, Pingjiang industry park and Xiangtan city Yuhu district new industrialization demonstration base, 10 provincial civil-military combination industry base and 10 competitive civil-military combination industries including dual-use nuclear energy industry, dual-use aviation industry, dual-use spaceflight industry, dual-use explosive materials industry, dual-use opto-electronics industry, dual-use special materials industry, automobile and parts industry, dual-use engineering machinery industry, dual-use fine chemical industry and dual-use shipbuilding industry. From angle of province level, strategy problem of regional economic development is selecting and cultivating leading industry scientifically. Therefore, this paper aims to promoting development of civil-military combination industry by analyzing its developing state and estimating leading industry under circumstance of complex regional background and national policy.

\section{Developing State of Civil-military Combination Industry of Hunan Province}

Hunan province has determined 10 competitive civil-military combination industries which form industrial advantage and cluster basically, their annual production value amount to 200 billion and its growth rate is $30 \%$. They can be divided into 3 levels obviously: firstly, automobile and parts industry belong to high level and its annual production value is 50 billion; secondly, dual-use opto-electronics industry, dual-use nuclear energy industry and dual-use special materials industry belong to middle level whose value is about 20 billion; thirdly, others belong to low level whose value is below10 billion. Three level exists significant difference, so third level can't be called industry cluster which should be developed deeply.

\section{Evaluations of Leading Civil-military Combination Industry of Hunan province}

This paper estimates leading civil-military combination industry of Hunan province by 6 indexes including regional developing phase, demand structure, factor endowment, industry policy, auxiliary industry development and income elasticity according to relative literature and industry data to do qualitative and quantitate research. 


\subsection{Regional Developing Phase}

Regional development phase also covers pre-industrial, beginning, midterm, later and postindustrial referring to national developing phase, which can be judged by quantum, structure and living quality. Obtaining results by data of "Hunan Province National Economy and Society Developed Statistical Bulletin 2016": 7170 dollars GDP per capita, later; tertiary industry output ratio is $11.5: 42.2: 46.3$, midterm; Industrial added value ratio is $35.8 \%$, midterm; non-food expenditure ratio $70.1 \%$, post-industrial; urbanization rate is $52.75 \%$, midterm. Although unbalanced development, this paper makes a conclusion that Hunan province can be listed in later industrial phase according to inter-index weight 25:20:15:15:25.

Leading industry of Hunan province should be automobile, petroleum, steel, durable consumer goods at later industrial phase or information industry at post-industrial phase. There are 8 relative industries in 10 competitive industries which are dual-use aviation industry, dual-use spaceflight industry, dual-use opto-electronics industry, dual-use special materials industry, automobile and parts industry, dual-use engineering machinery industry, dual-use fine chemical industry and dual-use shipbuilding industry, manifesting certain scientific policy of Hunan province.

\subsection{Regional Demand Structure}

Regional demand structure refers to regional requirements and variation, which can be depicted by industrial growth, that is national requirement is expanding when industrial growth rate surpass per capita disposable income growth rate. Per capita disposable income growth rate is $8.1 \%$, while 10 civil-military combination industry average growth rate is $31.1 \%$ which is $22.0 \% 、 36.0 \% 、 52.0 \%$ 、 $29.8 \% 、 29.0 \% 、 30.0 \% 、 22.0 \% 、 46.0 \% 、 34.0 \%$ and $41.0 \%$ respectively. Therefore, regional demand structure of Hunan province is favorable.

\subsection{Regional Factor Endowment}

Regional factor endowment mainly refers to capital, human resource and technology according to technical characteristic of civil-military combination industry. At year 2017, Hunan province impels 55 major projects whose total investment amount to 97.4 billion; ratio of national defense-related science and technology lab and nation defense characteristic discipline reach $8.4 \%$ and $10 \%$ exceeding nation average expense; gains 177 awards at ministerial and provincial-level, among which also gains 37 awards at nation level; patent application amounts to 3500 while patent authorization amounts to 1500 . In general, Hunan province is abundant in capital, human resource and technology.

\subsection{Regional Industry Policy}

Regional industry policy is pretty good in Hunan province. There are 136 main projects and their investment amount to 81 billion during $11^{\text {th }} 5$-year plan while investment is 67,23 billion during $12^{\text {th }}$ 5-year plan accordingly. At year 2017, Hunan province impels 55 major projects whose investment amount to 97.4 billion. General speaking, investment is growing and universities' engagement is boosting too which means technology innovation can propel industrial development well.

\subsection{Auxiliary Industry Development}

Civil-military combination industries of Hunan province are mostly distributed in every industrial base which have compelte infrastructure and industrial chains. Take Pingjiang industrial base as example, it named as "attract investment by perfect facilities and function" who achieves construction including water, electricity, highway, telecommunication, sewerage system and smooth land, and it also has international and powerful enterprises including Orica, Nanling, Shenfu etc. forms 4 integrated industry cluster which are explosive equipment, equipment manufacturing, new material and electronics technology. In summary, industrial park is effective way to develop civil-military combination industries which has sufficient facilities and industrial chains.

\subsection{Regional Income Elasticity}

Income elasticity refers to ratio of industrial production value growth rate to resident income growth rate (see formula 1) which means influence of industrial development to resident welfare, if $\mathrm{E}>1$, this industry can be treated as leading industry, vice versa. Getting data of resident income growth rate from "Hunan Province National Economy and Society Developed Statistical Bulletin" to calculate E, while production value growth rate of 2007-2008 is real but 2010-2015 is planning. 
$\mathrm{E}=\frac{\mathrm{dX}}{\mathrm{d} Y} \mathrm{Y}$, here $\mathrm{X}$ is indutrial production value growth rate, $\mathrm{Y}$ is resident income growth rate

Table 1 Income Elasticity of Civil-military Combination Industries in Hunan Province

\begin{tabular}{|c|c|c|c|c|c|c|}
\hline Industry & 2007 & 2008 & 2009 & 2010 & 2012 & 2015 \\
\hline Dual-Use Nuclear Energy Industry & 9.52 & 2.46 & 1.58 & 3.23 & 1.68 & 2.59 \\
\hline Dual-Use Aviation Industry & 0.57 & 4.88 & 2.95 & 5.54 & 2.75 & 4.24 \\
\hline Dual-Use Spaceflight Industry & 2.07 & 3.21 & 4.74 & 7.69 & 3.97 & 6.12 \\
\hline Dual-Use Explosive Materials Industry & 1.66 & 2.96 & 2.84 & 4.49 & 2.24 & 3.51 \\
\hline Dual-Use Opto-Electronics Industry & 2.76 & 7.07 & 2.42 & 4.46 & 2.21 & 3.41 \\
\hline Dual-Use Special Materials Industry & 1.99 & -1.89 & 1.58 & 4.31 & 2.29 & 3.53 \\
\hline Automobile And Parts Industry & 1.91 & 2.48 & 1.89 & 3.69 & 1.68 & 2.59 \\
\hline $\begin{array}{l}\text { Dual-Use Engineering Machinery } \\
\text { Industry }\end{array}$ & 0.62 & 0.52 & 4.21 & 7.08 & 3.51 & 5.41 \\
\hline Dual-Use Fine Chemical Industry & 4.61 & -1.88 & 1.05 & 5.08 & 2.60 & 4.00 \\
\hline Dual-Use Shipbuilding Industry & 4.98 & 6.16 & 4.11 & 6.15 & 3.05 & 4.82 \\
\hline
\end{tabular}

According to Tab.1, industry income elasticity from year 2007-2015 manifests fluctuant growing, even dual-use special materials industry and dual-use fine chemical industry is negative, which may be relative to their characteristic of scale economy. In general, all industries have preferable developing prospect, dual-use spaceflight industry and dual-use engineering machinery industry can mostly promote resident income whose E value reaches more than 5. Overall, majority of civilmilitary combination industry is good for economy and welfare.

\section{Optimizations of Leading Civil-military Combination Industry of Hunan Province}

Choosing some leading industry to give priority to develop is unconventional pattern to promote regional high-speed development based on macro-strategy. General speaking, selection of provincial leading industry should take reference to successful experience and practice of developed country or region, reginal advantage and inter-provincial cooperation. Therefore, Hunan province should do adjustments to optimize leading civil-military combination industry.

\subsection{Focusing On 2-3 Certain Industries}

Hunan province comes up with viewpoint that it has taken shape industrial pattern contains 6 leading industries from 10 competitive industries which are backbone industries referring to nuclear, aviation, spaceflight, special equipment manufacturing, shipbuilding, explosive and fine chemical, and 3 characteristic industries including new energy, new material and military electronics industry etc. Although there are 8 in 10 competitive industries have close connection or coincidence with laterindustrial age and post-industrial age, it should more focusing and concise which can help to form core competitiveness industry and industrial cluster. Therefore, Hunan province should choose 2-3 leading industries based on 10 competitive industries, 6 backbone industries and civil-military combination industries developing state nowadays, which help invest limited resource of Hunan province to key projects and industry.

\subsection{Deepening Industrial Development}

Although civil-military combination industries are developing well yearly, they haven't play important role in national economy, the crux of mater is that its role isn't strengthened and deepened. Therefore, Hunan province should launch relevant policies and resources to support forcefully and help to form provincial developing points. Specific measures contains establishing "government, industry, university\& research" cooperation information sharing mechanism which can reinforce information communication and sharing between military and civilian, making full play of military and civilian to lead powerful enterprises to join military projects and colleges do higher-end research; industrial parks should construct industrial chain and ancillary facilities based on scientific analysis and experience of demonstration base which help local civil-military industries develop in virtuous circle; adopting talent strategy who can fully drive industrial development. In addition, dual-use 
special materials industry and dual-use fine chemical industry has little significance with income increase from index of income elasticity. Hunan province should keep balanced development among different industries in order to preventing appearance of developing short slab.

\subsection{Synchronizing with National Policy}

According to “Directory of Military Technology Transferring to Civilian 2015” compiled by Ministry of Industry\& Information Technology, civil-military industry refers 9 technology field containing public security, intelligent manufacturing, emergency rescue, energy conservation and environment protection, kinetic energy and transmission, nuclear technology applications, space technology applications, general aviation and ocean engineering equipment. 136 key construction projects in civil-military combination industry $11^{\text {th }}$ 5-year plan of Hunan province and 67 key construction projects in $12^{\text {th }} 5$-year plan are different with directory above which lead to different developing requirements and conflict existing at area of policy support and resource guarantee, it would be more trouble if corporations are cross-region management. Therefore, policies issued by Hunan province should synchronize with national policy in order to reduce policy explanations and implement puzzles in developing civil-military combination industries.

\section{References}

[1]. Wencan Tang. Definition and Classification of Civil-military Industry. Defense Science \& Technology Industry. (2014) No. 7, p. 42-43.

[2]. Luning Lin. Thinking of Establishment National New Industrialization Civil-military Industry Demonstration Base of Xiangtan City, Defense Industry Conversion in China, (2013) No. 4, p. 22-25.

[3]. Yanlian Chen, Haisheng Cai, Liansheng Lin. Review on Selection of Regional Leading Industry. Contemporary Economics. (2013) No. 15, p. 142-144.

[4]. Xiao Yang, Li Zeng. Depending on Civil-military Combination Industry Demonstration Base, Promoting New Industrialization Development of Hunan Province. Huxiang Forum. Vol. 42 (2013) No. 6, p. 71-74, 85.

[5]. Xiaohui Dong, Li Zeng, Chaofeng Huang. Analysis on Developing state and Countermeasures of Civil-military industry Cluster_— Taking Hunan Province for Example. Science \& Technology Progress and Policy. Vol. 29 (2012) No. 1, p. 59-63. 